\title{
EVALUATION OF LIGHTING FOR VISUAL PERFORMANCE IN PPAG OFFICE BUILDING PARAHYANGAN CATHOLIC UNIVERSITY, BANDUNG
}

\author{
${ }^{1}$ Eva Saraswati. ${ }^{2}$ Ariani Mandala, S.T., M.T. \\ ${ }^{1}$ Student in the Bachelor's (S-1) Study Program in Architecture \\ at Parahyangan Catholic University \\ ${ }^{2}$ Senior lecturer in the Bachelor's (S-1) Study Program in Architecture \\ at Parahyangan Catholic University
}

\begin{abstract}
Lighting (daylight and artificial) for office is meant for work performance and comfort. The main purpose is to make the task easily identified. Illumination level and glare are indicators for visual performance. PPAG office at Parahyangan Catholic University is now used to accommodate administrative activities by technic faculty's staffs. PPAG office has some physical conditions that affecting its visual performance. Room and furniture layout, light source position and transparent façade affect the illuminance level on the task, and may cause direct and indirect glare from the sun and lamp.

This evaluative research is using comparative method, by comparing on-site data with literatures; and explorative-descriptive to analyze data: exploring impact and causes that being explained descriptively. Illumination level measurement was done digitally using dialux evo to get a precise and quicker result, and sun glare possibilities are assessed by studying the horizontal sun shading effectiveness.

Research concludes that visual performance in PPAG office is less than optimal, where 77,9\% illumination level at its visual task are measured to be less than its standard, some sun glare at east and west zones, and indirect glare from reflected light on the desk in cubicle room. Therefore it could be optimalized by correcting the furniture layout, rezoning, and adding some shading elements.
\end{abstract}

\section{EVALUASI PENCAHAYAAN UNTUK PERFORMA VISUAL PADA KANTOR GEDUNG PPAG UNIVERSITAS KATOLIK PARAHYANGAN, BANDUNG}

\author{
${ }^{1}$ Eva Saraswati. ${ }^{2}$ Ariani Mandala, S.T., M.T. \\ ${ }^{1}$ Mahasiswa S1 Program Studi Arsitektur Universitas Katolik Parahyangan \\ ${ }^{2}$ Dosen Pembimbing S1 Program Studi Arsitektur Universitas Katolik Parahyangan
}

\begin{abstract}
Abstrak- Pencahayaan alami dan buatan pada kantor ditujukan untuk mendukung performa dan kenyamanan kerja. Hal itu dicapai dengan membuat tugas mudah untuk diidentifikasi. Tingkat iluminasi dan silau merupakan indikator performa visual, yaitu kemampuan mata mengidentifikasi tugas. Kantor PPAG di lingkungan Universitas Katolik Parahyangan digunakan untuk mewadahi kegiatan administratif akademis karyawan fakultas teknik. Kantor memiliki beberapa kondisi fisik yang mempengaruhi performa visual. Tata letak ruang dan perabot, posisi sumber cahaya, dan pelingkup bangunan yang transparan mempengaruhi tingkat iluminasi pada bidang kerja dan memiliki potensi silau ke mata pengamat.

Penelitian yang bersifat evaluatif ini menggunakan metode komparasi, yaitu membandingkan data lapangan dengan kajian literatur; dan eksploratif-deskriptif untuk menganalisis data: mengeksplorasi dampak dan penyebab yang dijelaskan secara deskriptif. Pengukuran iluminasi dilakukan secara digital menggunakan program
\end{abstract}

${ }^{1}$ Corresponding Author: evasrswt@gmail.com 
dialux evo untuk mendapatkan hasil yang lebih cepat dan presisi, sedangkan kajian silau dilakukan dengan menguji efektifitas SPSM horizontal pada bangunan.

Penelitian menyimpulkan bahwa performa visual pada kantor PPAG kurang optimal, yaitu tingkat iluminasi sebesar 77,9\% kurang dari standar, potensi silau matahari pada sisi barat dan timur, serta potensi silau dari cahaya reflektif pada meja kerja ruang kubikal. Pengoptimalan dapat dilakukan dengan mengatur peletakkan perabot, penempatan zoning yang sesuai, dan penggunaan elemen pembayangan tambahan.

Kata Kunci: pencahayaan, performa visual, kantor PPAG Unpar

\section{PENDAHULUAN \\ 1.1 LATAR BELAKANG}

Esensi pencahayaan pada kantor ditujukan untuk kemampuan bekerja dan kenyamanan kerja. Hal itu dicapai dengan membuat pekerjaan lebih mudah, menciptakan identitas, mendukung kesehatan, dan mendukung kondisi karyawan sebagai bentuk investasi (Zumtobel, 2017). Untuk membuat pekerjaan lebih mudah, pencahayaan dirancang untuk mendukung performa visual. Performa visual diartikan sebagai kemampuan identifikasi. Performa visual ditinjau dari kondisi pencahayaan dipengaruhi oleh kuat iluminasi dan silau. Kedua indikator ini dapat mengganggu visibilitas tugas dan mempersulit tugas visual.

Kantor di gedung Pusat Pembelajaran Arntz-Geise (PPAG) di Universitas Katolik Parahyangan (Unpar) beroperasi pada siang hari, sehingga ruang kerja mendapatkan dua sumber cahaya yaitu pencahayaan buatan dan alami. Bangunan yang didominasi pelingkup transparan pada semua sisi memungkinkan ruangan untuk mendapatkan penetrasi cahaya alami yang dapat menambah tingkat iluminasi pada ruang kerja. Meski demikian, ruang kantor memiliki beberapa kondisi seperti bentuk yang terlalu luas dan adanya elemen penghalang di sekitar bangunan, sehingga tidak semua ruang kerja mendapatkan pencahayaan alami. Akhirnya, mayoritas aktivitas yang ditampung di kantor PPAG bergantung pada pencahayaan buatan yang didistribusikan secara merata. Selain dapat menambahkan tingkat iluminasi, penetrasi cahaya alami juga berpotensi menimbulkan silau yang mengganggu kenyamanan visual pada tugas.

Kantor PPAG yang digunakan untuk kegiatan administratif ${ }^{2}$ sebagai kegiatan utama ini memiliki beberapa tipologi ruang seperti bentuk kubikal dan open plan. Penataan ruang serta letak perabotnya yang beragam, menyebabkan letak sumber cahaya yang cukup beragam terhadap bidang kerjanya. Hal ini memungkinkan terdapat kondisi di mana bidang kerja tidak mendapatkan tingkat iluminasi yang memadai, atau malah berlebihan.

Faktor performa visual tentunya penting untuk dipertimbangkan mengingat kantor PPAG yang tidak hanya digunakan untuk tempat mengerjakan tugas/bekerja, juga menjadi tempat bernaung sehari-hari bagi beberapa penghuni yang menggunakan ruang secara intensif. Ragam kondisi lingkungan visual yang berbeda-beda perlu dipelajari untuk dinilai pengaruhnya terhadap performa visual penggunanya. Ruang kantor akan dirancang ulang, maka penelitian evaluasi dapat dilakukan sebagai pertimbangan perancangan kantor di waktu yang akan datang.

Penelitian ini menitikberatkan pada pengaruh penataan ruang, letak perabot dan posisi sumber cahaya terhadap aspek performa visual pelaku aktivitas. Pertanyaan penelitian adalah sebagai berikut.

1. Bagaimana kondisi lingkungan visual pada ruang kerja kantor PPAG yang mempengaruhi performa visual?

${ }^{2}$ Kegiatan administratif yang berkaitan kegiatan akademis, terbatas pada kegiatan baca-tulis, penggunaan layar monitor dan alat ketik. 
2. Apakah kondisi fisik pada ruang kerja kantor PPAG mendukung performa visual secara optimal?

\section{KAJIAN TEORI}

\subsection{PERFORMA VISUAL PADA KANTOR}

\section{A. Elemen Pembentuk Ruang}

Ruang digambarkan sebagai suatu area yang memiliki batasan fisik yang terbaca. Batasan fisik tersebut mencakup bidang horizontal dan bidang vertikal. Batasan fisik ruang ini disebut elemen pelingkup, sedangkan elemen yang berada di dalamnya disebut elemen pengisi (perabot). Elemen pengisi pada suatu lingkungan visual mencakup bidang pemantul cahaya dan bidang kerja. Bidang kerja merupakan area di mana suatu tugas visual dilakukan, misalnya pada bidang meja dan pada layar monitor.

Permukaan bidang yang mencakup material, warna dan finishing berupa tekstur dan tingkat kilau, dapat mempengaruhi kondisi visual. Warna cerah dapat merefleksikan cahaya secara efektif, sedangkan warna permukaan yang gelap cenderung menyerap cahaya. Tekstur yang halus lebih banyak merefleksikan cahaya, sedangkan bidang yang bertekstur lebih bersifat membaurkan cahaya.

\section{B. Pencahayaan}

Aspek yang membedakan karakter cahaya antara lain yaitu warna temperatur cahaya, kuat penerangan/iluminasi dan kemampuan renderasi warna. Intensitas/kepadatan suatu cahaya yang dihasilkan dibandingkan dengan luas bidang sumber cahaya disebut iluminasi, diukur dengan satuan lux. Tingkat iluminasi sangat terkait dengan tingkat kecerahan (brightness). Jika iluminasi adalah apa yang dibaca oleh alat pengukur cahaya, maka kecerahan/brightness adalah apa yang kita lihat.

\section{Pencahayaan Alami}

Pencahayaan alami dibedakan menjadi dua yaitu cahaya matahari dan cahaya langit. Cahaya langit merupakan cahaya matahari yang didifusikan atmosfer. Cahaya langit inilah yang menjadi sumber pencahayaan alami utama pada bangunan, karena cahaya matahari beresiko silau dan radiasi panas jika tidak dikontrol (Ruck, 1989). Pencahayaan alami yang masuk ke dalam bangunan dibedakan menjadi tiga: cahaya matahari langsung; cahaya difus dari terang langit; cahaya difus dari pantulan tanah atau bangunan.

Terdapat beberapa faktor yang mempengaruhi kuantitas dan kualitas pencahayaan alami, yaitu kondisi langit dan kondisi bangunan. Kondisi langit meliputi waktu penyinaran, posisi geografis, dan komponen langit. Sedangkan data bangunan yaitu geometri bangunan dan ruang, bukaan, faktor refleksi, kontribusi pencahayaan buatan, elemen penghalang, perawatan, polusi, dan isi ruang (Mandala, 2016).

\section{Pencahayaan Buatan}

Tingkat iluminasi pencahayaan buatan dipengaruhi oleh karakteristik lampu dan material bidang pemantul di sekitar lingkungan visual. Karakteristik cahaya dibedakan berdasar intensitas, temperatur warna, dan kemampuan renderasi warnanya.

\section{Cahaya Refleksi}

Sumber cahaya selain langsung dari langit atau luminer, juga dapat datang dari pantulan bidang di sekelilingnya. Suatu bidang memiliki nilai refleksi dan nilai transmisi tergantung dari finishing dan material permukaannya.

\section{Performa Visual pada Kantor}


Pembahasan mengenai performa visual diambil dari dua literatur yaitu Lighting: Interior and Exterior oleh Robert Bean (2004) dan Heating, Cooling, Lighting oleh Lechner (2015).

Tabel 1. Kebutuhan Visual menurut Bean

\begin{tabular}{|c|c|c|c|c|}
\hline $\begin{array}{l}\text { Kebutuhan } \\
\text { Visual }\end{array}$ & \multicolumn{2}{|c|}{ Definisi } & \multicolumn{2}{|r|}{ Kriteria Pencahayaan } \\
\hline $\begin{array}{l}\text { Kenyamanan } \\
\text { Visual }\end{array}$ & \multicolumn{2}{|c|}{$\begin{array}{l}\text { Kesehatan/well-being (EN } \\
12665,2012)\end{array}$} & \multicolumn{2}{|c|}{ Mereduksi silau, tingkat cerah dan kon } \\
\hline Kepuasan Visual & \multicolumn{2}{|c|}{$\begin{array}{l}\text { Efek psikovisual dan kebutuhan } \\
\text { biologis }\end{array}$} & \multicolumn{2}{|c|}{ Adanya view keluar bangunan, dayligh } \\
\hline \multirow[t]{9}{*}{ Performa Visual } & \multicolumn{2}{|c|}{$\begin{array}{l}\text { Kemampuan identifikasi (Egan, } \\
\text { 2002) }\end{array}$} & \multicolumn{2}{|c|}{ Tingkat iluminasi dan distribusi cahaya } \\
\hline & \multicolumn{3}{|c|}{ PERFORMA VISUAL } & \multirow[b]{2}{*}{$\downarrow$} \\
\hline & & & 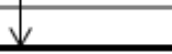 & \\
\hline & Tugas & \multicolumn{2}{|c|}{ Kondisi pencahayaan } & Kondisi Pengamat \\
\hline & Ukuran objek & \multicolumn{2}{|c|}{$\rightarrow \quad$ Tingkat iluminasi } & Kondisi mata \\
\hline & $\rightarrow$ Waktu eksposur & \multicolumn{2}{|c|}{$\rightarrow$ Rasio tingkat cerah } & Adaptasi \\
\hline & $\rightarrow \quad$ Tingkat cerah & $\rightarrow$ & Silau & Tingkat lelah \\
\hline & Kontras & & & Kesehatan \\
\hline & Familiaritas & & & $\rightarrow$ Efek obat/alkohol \\
\hline
\end{tabular}

: Aspek yang diteliti pada penelitian

Figur 1. Diagram faktor berpengaruh terhadap performa visual menurut Lechner

Performa visual dapat diartikan sebagai kemampuan mengidentifikasi tugas. Kemampuan seseorang untuk mengerjakan suatu tugas visual tergantung dari bagaimana mata mengidentifikasi detil dari tugas. Faktor yang mendeterminasikan visibilitas suatu tugas adalah ukuran tugas, tingkat pencahayaan, kontras, dan silau (PG\&E, 1997). Iluminasi yang memadai diperuntukkan untuk menjamin performa visual. Tingkat iluminasi pada dasarnya juga relatif, tergantung pada keadaan penggunanya seperti kemampuan penglihatan dan usia pengguna.

\section{Tingkat Iluminasi}

Kuantitas cahaya pada bidang kerja dapat dipengaruhi oleh tingkat iluminasi, dimensi ruangan dan faktor refleksi pada lingkungan sekitar bidang kerja dan oleh bidang kerja itu sendiri. Iluminasi akan berbanding secara proporsional terhadap tingkat cerah. Seiring peningkatan tingkat iluminasi atau tingkat cerah, pupil mata akan mengecil (Lechner, 2015). Standar pencahayaan menunjukkan tingkat cahaya minimum untuk jenis-jenis ruangan yang berbeda, contohnya yaitu standar Eropa (EN 12454-1).

Tabel 2. Tingkat pencahayaan minimum direkomendasikan pada fungsi perkantoran menurut standar Eropa (EN 12464-1)

\begin{tabular}{|l|l|}
\hline Type of interior, task or activity & $\mathrm{E}_{\mathrm{m}}(\mathrm{lx})$ \\
\hline Filing, copying,etc. & 300 \\
\hline Writing, typing, reading, data processing & 500 \\
\hline Technical drawing & 750 \\
\hline CAD work stations & 500 \\
\hline Conference and meeting rooms & 500 \\
\hline Reception desk & 300 \\
\hline
\end{tabular}



200

\section{(Sumber: EN-12464-1)}

Selain pencahayaan pada bidang kerja, EN 12464-1 juga menyertakan standar untuk lingkungan sekitar area kerja atau bidang kerja, disebut area sekitar (immediate surrounding). Rekomendasi iluminasi pada area sekitar bidang kerja ini pada dasarnya adalah satu tingkat di bawah skala berikut:

$$
20 \text { - } 30 \text { - } 50 \text { - } 75 \text { - } 100 \text { - } 150 \text { - } 200 \text { - } 300 \text { - } 500 \text { - } 750 \text { - } 1000 \text { - } 1500 \text { - } 2000 \text { - } 3000 \text { - } 5000
$$

Iluminasi yang diperlukan harus dinaikkan apabila tugas visual kritis, antisipasi terhadap kesalahan (error) sangat diperlukan, akurasi atau produktivitas yang tinggi adalah sangat penting, kemampuan visual pengguna di bawah normal, detil tugas sangat kecil atau kontrasnya rendah, dan bila tugas dilakukan dalam periode yang lama. Sebaliknya, iluminasi dapat diturunkan apabila detil tugas besar atau dalam kontras yang tinggi, dan apabila tugas dilakukan pada waktu yang singkat. Pada area yang terus-menerus digunakan, iluminasinya tidak boleh kurang dari 200 lux.

\section{Silau}

Silau merupakan kondisi penglihatan di mana terdapat ketidaknyamanan atau pengurangan kemampuan untuk melihat detail atau objek, dikarenakan distribusi atau range luminasi yang tidak sesuai, atau kontras yang terlalu ekstrim (EN, 2012).

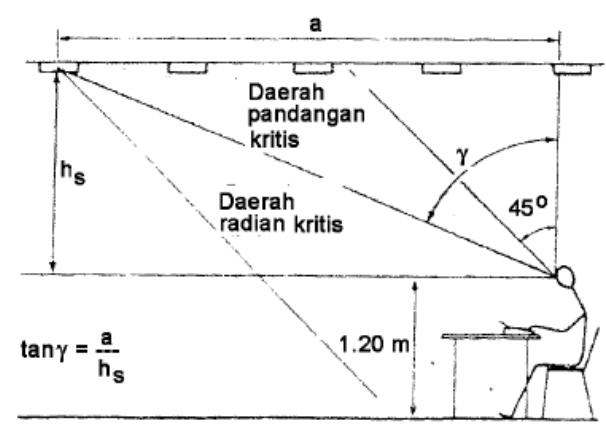

Figur 2. Zona yang menyinggung sudut visual (Sumber: SNI 03-6575, 2001)
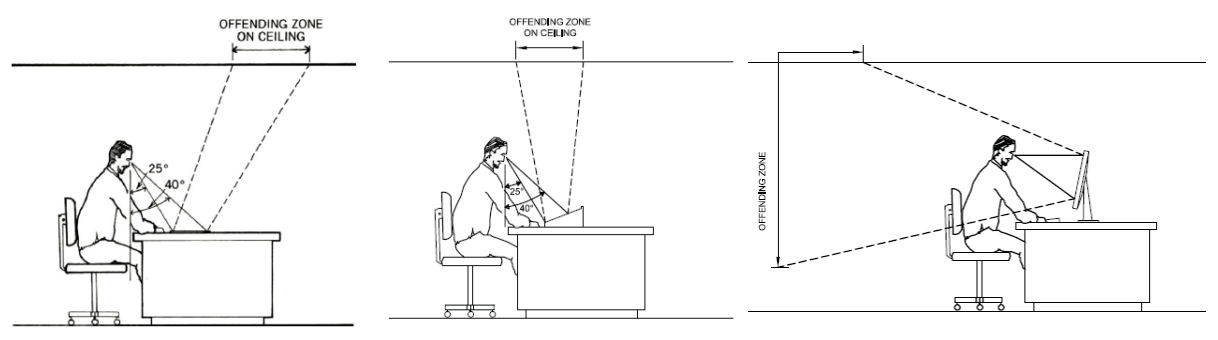

Figur 3. Silau yang menyinggung kerja visual

(Sumber: Heating, Cooling, Lighting, 2015)

\section{METODA PENELITIAN}

Metode yang akan digunakan adalah metode komparasi dan eksploratif-deskriptif. Penelitian dilakukan guna memperdalam pengetahuan mengenai pengaruh kondisi lingkungan terhadap performa visual pada kantor PPAG Unpar. Penelitian merupakan penelitian evaluatif, yang bertujuan mengeksplorasi (mencari tahu) dan mempelajari fenomena-fenomena yang terjadi pada objek studi melalui perbandingan dengan studi literatur. 
Tabel 3. Waktu dan Tempat Simulasi

\begin{tabular}{|l|l|l|}
\hline Tempat & $\begin{array}{l}\text { Ruang kerja (ruang tata usaha, ruang dosen, ruang-ruang kejurusan, } \\
\text { ruang-ruang pengurus fakultas, ruang rapat, ruang komputer) di kantor } \\
\text { gedung PPAG lantai 2. }\end{array}$ \\
\hline Koordinat & $107^{\circ} 36^{\prime}$ BT, $6^{\circ} 52^{\prime}$ LS \\
\hline Waktu setempat & UTC +7.00 (WIB) & Clear sky \\
\hline Kondisi langit & Overcast & Merujuk pada tabel 3 \\
\hline Tanggal simulasi & 21 Juni 2017 & Merujuk pada tabel 3 \\
\hline Waktu simulasi & 12.00 &
\end{tabular}

Selain pengukuran data yang terukur, dilakukan pula pengumpulan data dengan metode observasi terhadap aktivitas yang dominan dilakukan di kantor. Pengumpulan data kuantitatif berupa nilai iluminasi yang dilakukan secara digital menggunakan program dialux evo dilakukan dengan tahapan membuat model digital, menentukan titik ukur menggunakan metode SBI, menentukan waktu ukur, melakukan pengukuran, lalu melakukan pendataan. Standar iluminasi yang digunakan yaitu standar Eropa (EN 12464-1), baik iluminasi untuk bidang kerja maupun pada lingkungan sekitar. Untuk metoda pengukuran potensi silau, tahapan yang dilakukan yaitu memprediksi waktu potensi silau menggunakan solar chart, menentukan ruang sampel, lalu melakukan uji SPSM dengan sun protractor. Setelah dilakukan uji SPSM, akan diketahui rentang waktu di mana pada orientasi tersebut terjadi silau langsung oleh sinar matahari. Digunakan alat bantu program Sketchup untuk visualisasinya.

\section{ANALISA}

\subsection{EVALUASI PENCAHAYAAN PADA RUANG KERJA DI KANTOR PPAG}

Terdapat beberapa tipe ruang pada kantor PPAG. Ruang dosen yang berbentuk kubikal memiliki luas $7.8 \mathrm{~m}^{2}$. Ruang rapat memiliki luas 18, 26, 44.6 dan $50 \mathrm{~m} 2$. Ruang tata usaha berbentuk open plan, memiliki luas $112 \mathrm{~m} 2$. Lampu yang digunakan didominasi lampu TL TBS330 2x28w/840 merk Philips yang ditanam (recessed) ke plafon, dan ditunjang dengan beberapa lampu downlight LED 13 watt pada area-area sekunder. Titik lampu didominasi teknik pencahayaan merata (general lighting), meskipun pada beberapa area terdapat perbedaan kelompok peletakkan lampu. Tata letak ruang pada kantor PPAG adalah sebagai berikut. 

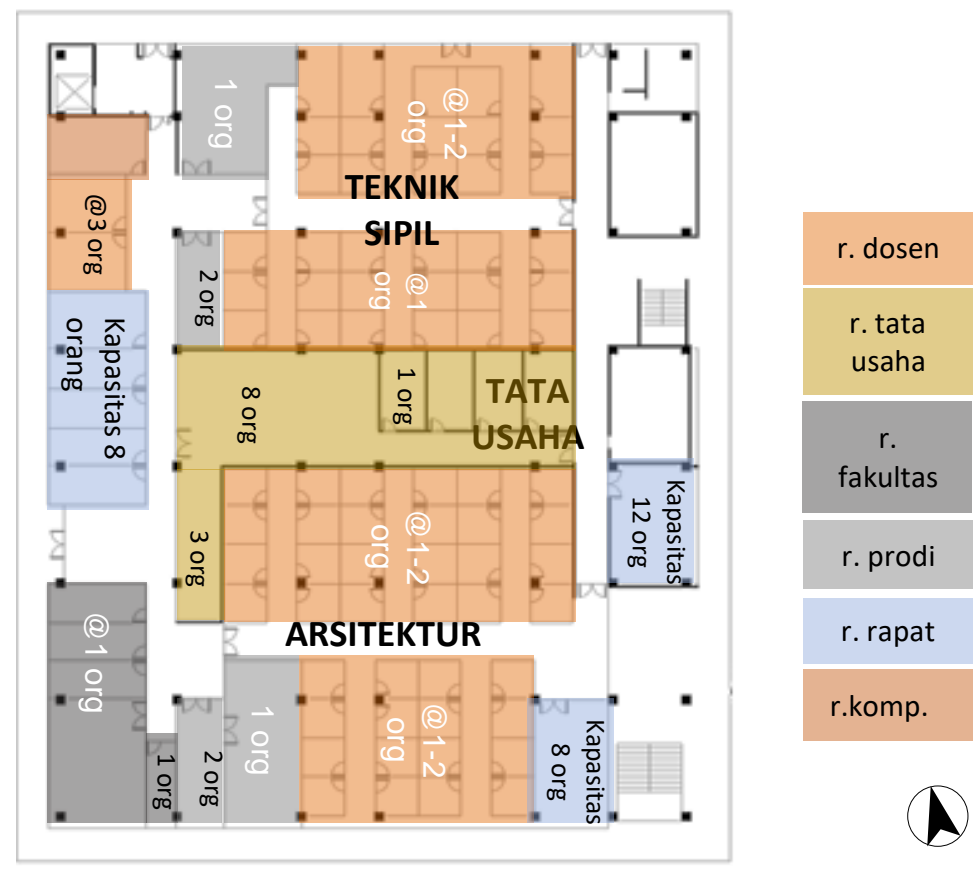

Figur 4. Data tata letak pada kantor PPAG

\subsection{KONTRIBUSI CAHAYA ALAMI}

Sebelum dilakukan pengukuran yang lebih detail, dilakukan penggambaran pencahayaan pada ruangan kantor yang ditunjukan pada figur 5 . Kondisi pencahayaan ini diukur dalam keadaan ruangan kosong dan dalam keadaan ruangan berpartisi, dalam keadaan cahaya alami merata (overcast).

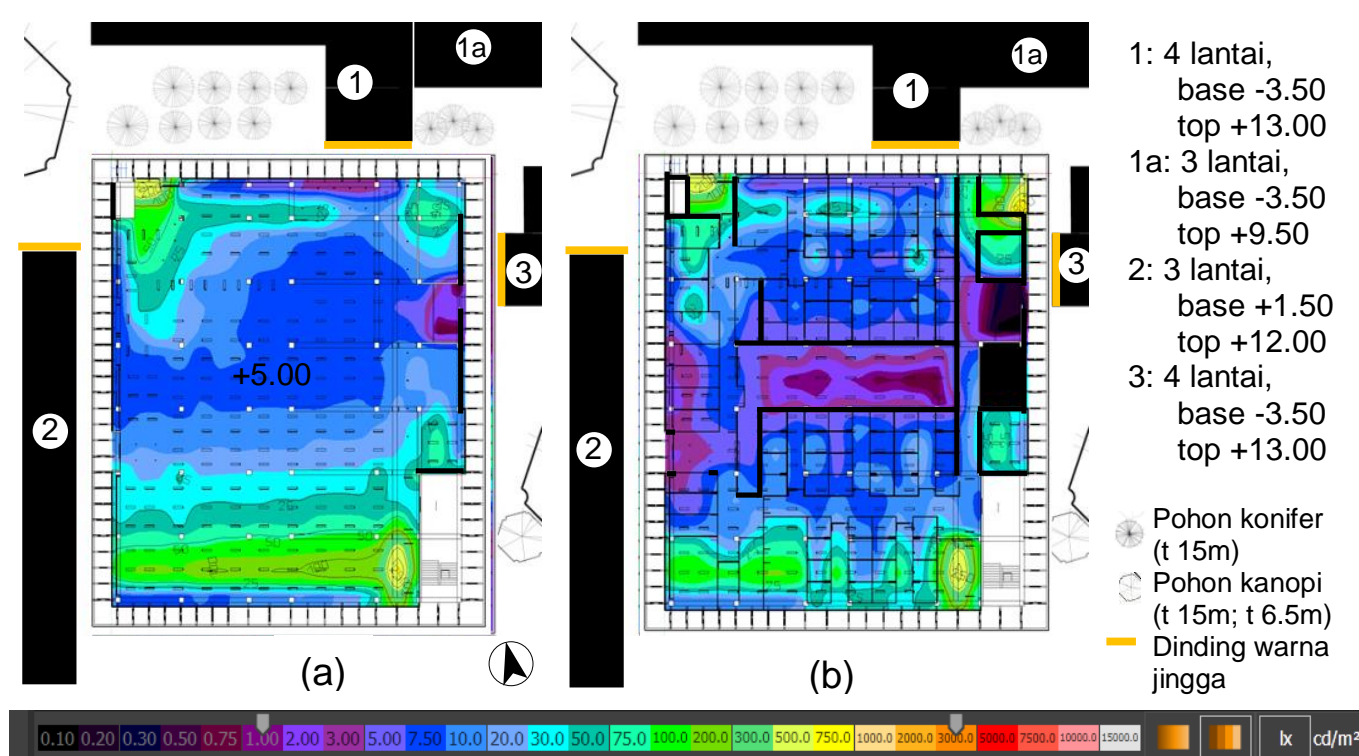

Figur 5. Distribusi cahaya alami pada ruang kantor PPAG dalam keadaan kosong (a) dan berpartisi (b)

Diukur dalam keadaan ruangan kosong, didapatkan jangkauan penetrasi pencahayaan alami pada daerah tertentu di ruang tepi. Jika dalam keadaan tanpa adanya elemen penghalang di luar bangunan, penetrasi cahaya alami dapat mencapai kedalaman 5-10 meter, seperti pada daerah selatan, barat dan timur. Ketika ruangan diisi dengan partisi, jangkauan penetrasi pencahayaan alami menjadi makin pendek. 
Penetrasi pencahayaan alami paling besar terletak pada sisi selatan di mana tidak terdapat elemen penghalang. Jika dimanfaatkan, dapat membantu mengurangi penggunaan energi untuk pencahayaan misalnya dengan menurunkan spesifikasi lampu pada area ini. Namun tidak bisa sepenuhnya bergantung pada pencahayaan alami karena tingkat iluminasinya rata-rata hanya mencapai 200 lux. Sisi timur juga memiliki potensi lubang cahaya karena adanya area luar yang kosong tanpa elemen penghalang. Namun kulit bangunan dibuat masif pada area tersebut, yang saat ini digunakan sebagai area servis. Zona barat hanya mendapatkan sedikit lubang cahaya efektif yang tidak terhalang gedung maupun pohon, dengan tingkat iluminasi rata-rata sebesar 100 lux. Sedangkan di sepanjang sisi utara terhalangi oleh elemen penghalang berupa gedung dan pohon, sehingga pada sisi ini tidak banyak mendapat penetrasi cahaya alami dan penetrasinya terbatas sebesar 50 lux.

Menanggapi perbedaan sumber cahaya, dilakukan pembagian zona ukur menjadi ruang tepi di mana terdapat pencahayaan buatan dan penetrasi cahaya alami, dan ruang tengah di mana hanya terdapat pencahayaan buatan.

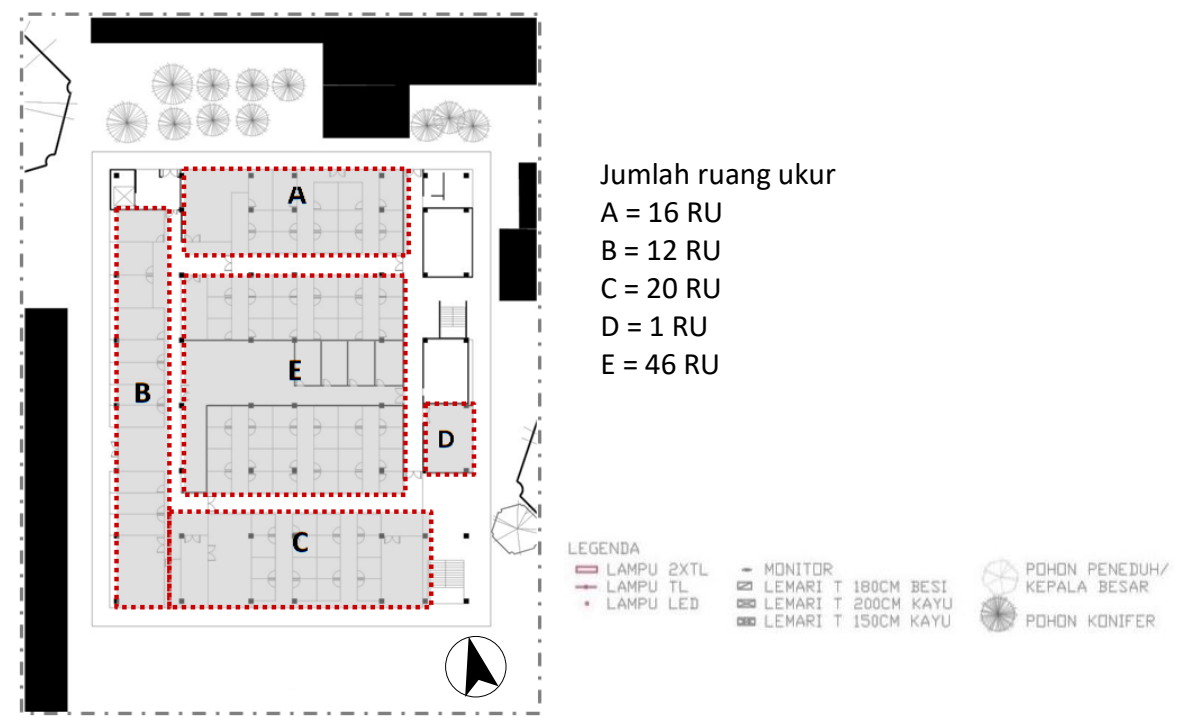

Figur 6. Zona ukur

Area tepi dibagi lagi menjadi beberapa zona, menanggapi kondisi ruang luar yang menyebabkan perbedaan jumlah penetrasi cahaya alami. Area tepi dibagi menjadi empat zona yaitu zona A, B, C, dan D, sedangkan area tengah yang tidak terjangkau cahaya alami menjadi zona E. Pengukuran pertama-tama dilakukan secara merata terhadap ruang ukur masingmasing zona, lalu lebih detil dilakukan pengukuran pada bidang kerja sebagai bentuk evaluasi performa visual terhadap kondisi yang ada.

\subsection{TINGKAT ILUMINASI}

\section{Zona A}

Tabel 4. Hasil Pengukuran Tingkat Iluminasi pada Zona A

\begin{tabular}{|c|c|c|c|c|c|c|}
\hline & \multirow{2}{*}{ Jml ruang ukur } & \multirow{2}{*}{$\begin{array}{l}\text { Jumlah titik } \\
\text { ukur }\end{array}$} & \multirow{2}{*}{$\begin{array}{l}\text { Rentang standar } \\
\text { iluminasi }(\mathrm{EN})\end{array}$} & \multicolumn{3}{|c|}{ Keterangan } \\
\hline & & & & $<$ & - & $>$ \\
\hline Merata & \multirow{2}{*}{16} & 702 & $270-330$ & $47.2 \%$ & $15.8 \%$ & $37 \%$ \\
\hline Bidang kerja & & 36 & $475-525$ & 36 & & \\
\hline
\end{tabular}




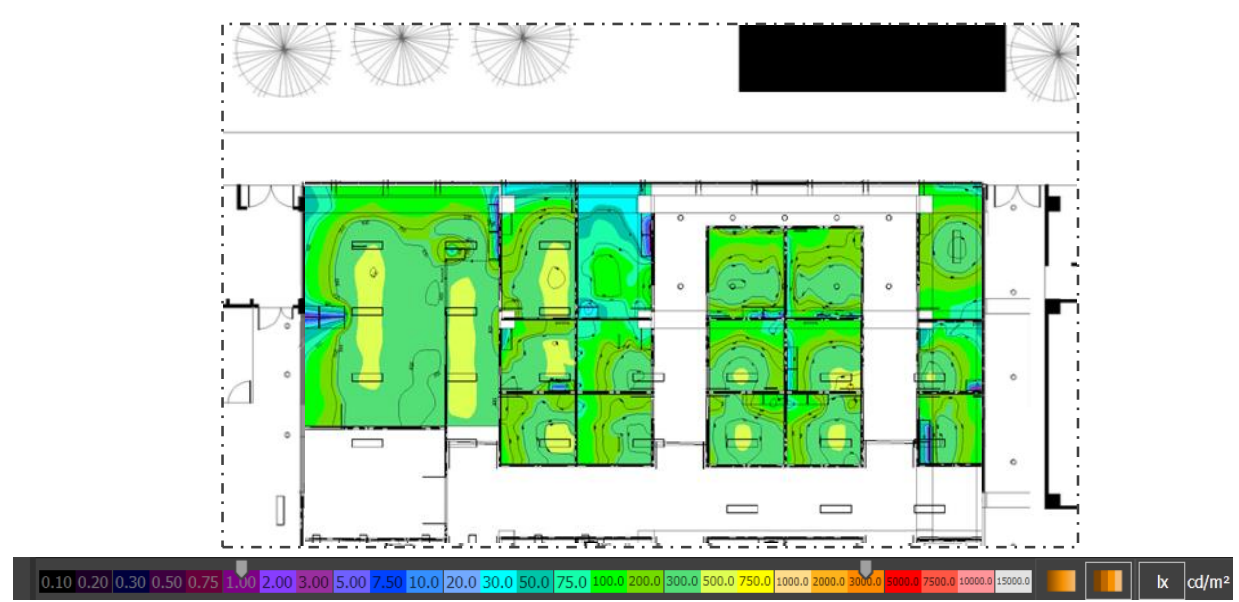

Figur 7. Pola distribusi pencahayaan alami dan buatan (total) pada zona A

Pada zona A, tingkat iluminasi yang merata pada ruang terukur cenderung rendah $(47,2 \%)$, dan sebagian lagi berlebih (37\%). Tingkat iluminasi pada bidang kerja di zona ini seluruhnya tidak mencapai standar. Letak titik lampu yang rata-rata berada di tepi-sudut ruangan menyisakan area dengan tingkat iluminasi yang rendah pada tepi lain ruangan, menyebabkan ruangan terkesan gelap. Pada ruang kubikal (ruang dosen), bidang kerja perlu berada di bawah atau di dekat lampu sehingga didapatkan tingkat iluminasi yang tepat pada bidang kerja.

Kuat iluminasi pada bidang kerja pada ruang yang bergantung pada penggunaan lampu LED mendapatkan tingkat iluminasi dengan nilai rata-rata paling rendah dibanding yang lain. Hal ini mengindikasikan bahwa karakteristik lampu kurang memenuhi kebutuhan pencahayaan untuk ruang kerja kantor.

\section{Zona B}

Tabel 5. Hasil Pengukuran Tingkat Iluminasi pada Zona B

\begin{tabular}{|c|c|c|c|c|c|c|}
\hline & \multirow{2}{*}{$\begin{array}{c}\text { Jumlah ruang } \\
\text { ukur }\end{array}$} & \multirow{2}{*}{$\begin{array}{l}\text { Jumlah } \\
\text { titik ukur }\end{array}$} & \multirow{2}{*}{$\begin{array}{l}\text { Rentang standar } \\
\text { iluminasi }(\mathrm{EN})\end{array}$} & \multicolumn{3}{|c|}{ Keterangan } \\
\hline & & & & $<$ & - & $>$ \\
\hline Merata & \multirow{2}{*}{12} & 799 & $270-330$ & $24.5 \%$ & $13.7 \%$ & $61.8 \%$ \\
\hline Bidang kerja & & 74 & $475-525$ & 50 & 10 & 14 \\
\hline
\end{tabular}

Pada zona B, tingkat iluminasi merata pada ruang terukur cenderung melebihi standar $(61,8 \%)$, dan pada bidang kerja kurang dari standar (50 dari 74 titik). Tingkat iluminasi pada bidang kerja ruang rapat yang sifatnya luas atau mendominasi luas ruangan menyisakan tingkat iluminasi pada lingkungan sekitarnya yang cukup rendah. Pada ruang rapat di mana layar proyektor juga digunakan, ruang yang sempit dan armatur lampu yang relatif dekat dapat mengurangi kontras pada layar proyektor. Latar belakang proyektor berupa bukaan yang mengarah ke luar bangunan, menciptakan bidang yang lebih terang dibandingkan layar proyektor, makin mengurangi kontras pada layar proyektor. Pada ruang RB02 dan RB03 di mana bidang kerjanya berada di pinggir ruangan, tingkat iluminasi sekitar bidang kerjanya cenderung lebih tinggi karena letak armatur lampu di tengah dan penetrasi cahaya alami. Hal ini dapat menciptakan keseragaman iluminasi antara bidang kerja dengan area sekitarnya yang dapat mengurangi kontras. 


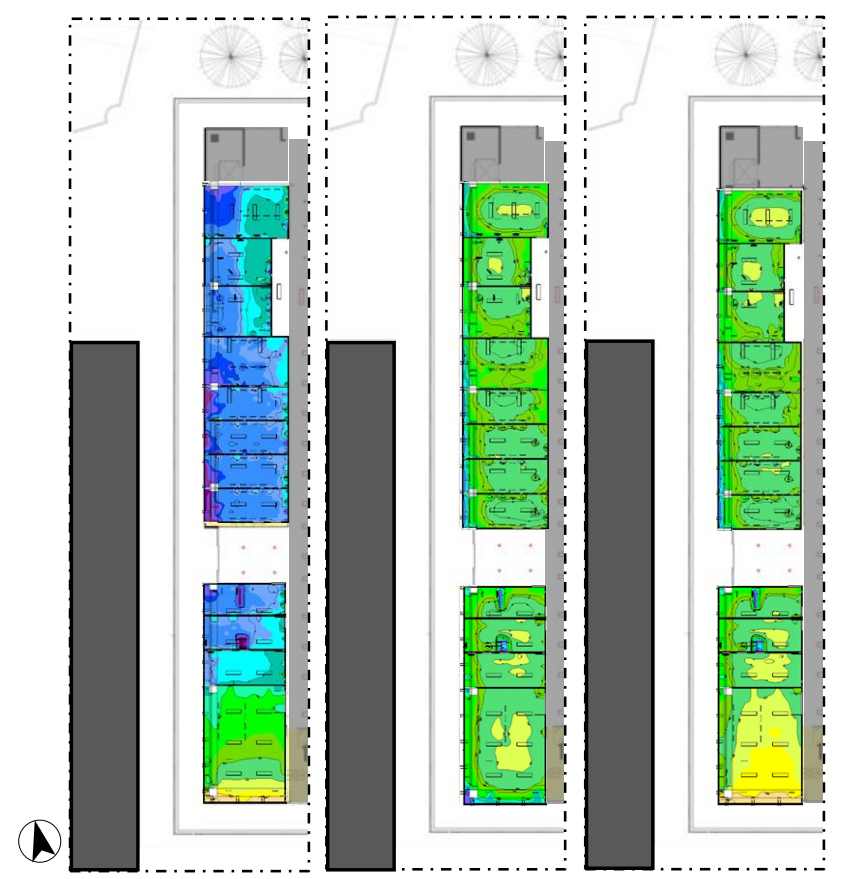

(a)

(b)

(c)

Figur 8. Pola distribusi pencahayaan alami (a), pencahayaan buatan (b), pencahayaan alami dan buatan/total (c) pada zona B

\section{Zona C}

Tabel 6. Hasil Pengukuran Tingkat Iluminasi pada Zona C

\begin{tabular}{|c|c|c|c|c|c|c|}
\hline & \multirow{2}{*}{ Jumlah r. ukur } & \multirow{2}{*}{$\begin{array}{c}\text { Jumlah titik } \\
\text { ukur }\end{array}$} & \multirow{2}{*}{$\begin{array}{c}\text { Rentang standar } \\
\text { iluminasi (EN) }\end{array}$} & \multicolumn{3}{|c|}{ Keterangan } \\
\cline { 4 - 7 } & \multirow{2}{*}{20} & 1315 & $270-330$ & $41.6 \%$ & $24.4 \%$ & $34.0 \%$ \\
\cline { 4 - 7 } & Merata & 46 & $475-525$ & 33 & 6 & 7 \\
\hline Bidang kerja & & & &
\end{tabular}

Pada zona C, tingkat iluminasi pada ruang cenderung kurang dari standar $(41,6 \%)$ dan melebihi standar (34\%). Pada bidang kerja, tingkat iluminasinya cenderung kurang dari standar (33 dari 46 titik ukur). Tingkat iluminasi pada bidang kerja yang melebihi standar berada ruang open plan karena kontribusi cahaya alami. Hal ini dapat menyebabkan pupil mata mengecil, menyebabkan ketidaknyamanan visual.

Beberapa tata letak monitor pada ruang-ruang tepi dengan arah sejajar bukaan/sumber cahaya alami sudah tepat untuk mengantisipasi silau, kecuali pada ruang kaprodi di mana letak monitor menghadap ke bukaan. Ruang rapat di sebelah tangga menggunakan layar proyektor, terletak di samping pintu. Pada ruangan meski dinilai tidak terlalu terang, namun jumlahnya yang besar $(81,3 \%)$ memberikan pencahayaan yang cukup merata pada ruangan. Oleh karena pencahayaan pada ruangan yang cukup merata, serta pelingkup ruangan yang seluruhnya berupa kaca, dapat mengganggu kontras untuk layar proyektor. 


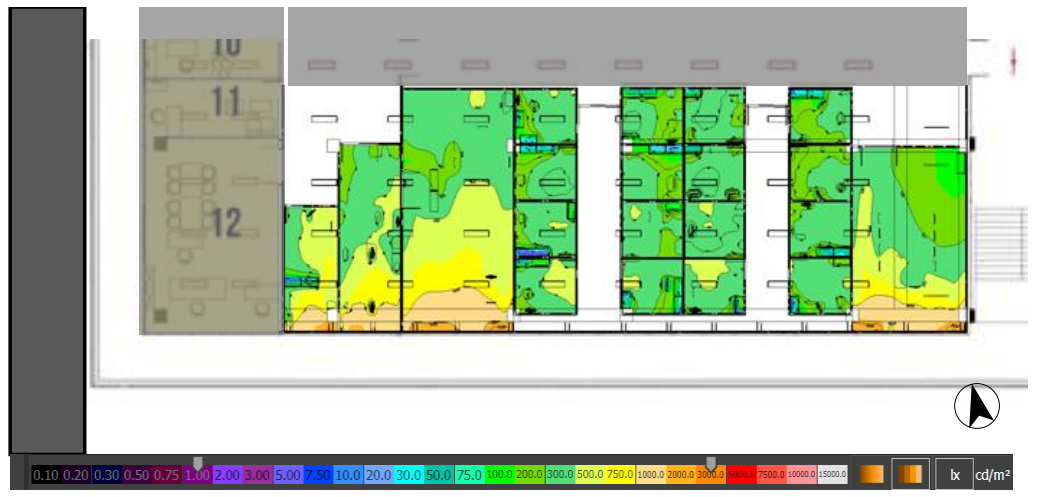

Figur 9. Pola distribusi pencahayaan alami dan buatan (total) pada zona C

\section{Zona D}

Tabel 7. Hasil Pengukuran Tingkat Iluminasi pada Zona D

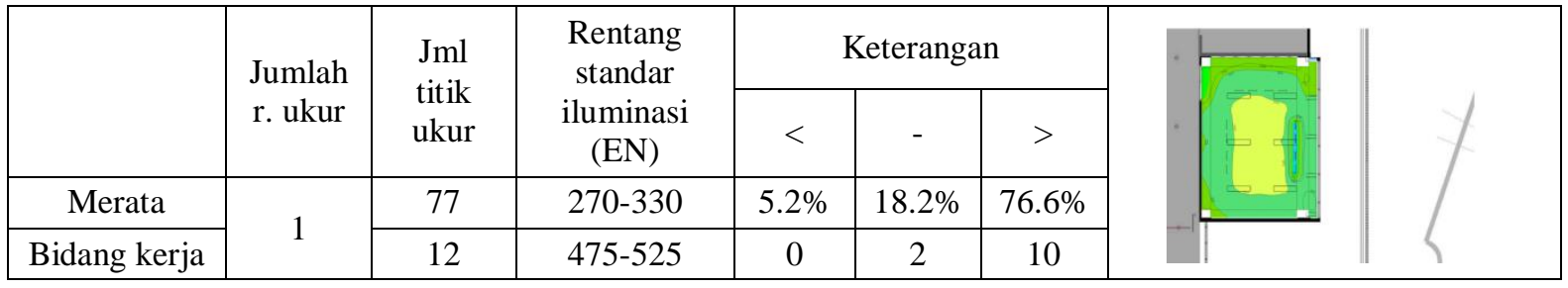

Pada zona D, tingkat iluminasi secara merata dan pada bidang kerja cenderung melebihi standar. Tingkat iluminasi yang melebihi standar pada ruang ini diiringi dengan fisik ruang yang didominasi bidang berwarna cerah (dinding, plafon, dan lantai) dapat mengurangi tingkat kontras pada bidang papan tulis dan layar proyektor yang ada pada ruangan ini. Jika ruangan digunakan ketika lampu dimatikan, keberadaan kolom memberikan kondisi yang tepat untuk layar proyektor, namun cukup gelap jika ruangan digunakan untuk baca-tulis dan ketika menggunakan papan tulis karena iluminasi cahaya alami hanya mencakup hingga 30 lux, meski letak cahaya jatuh condong di tengah ruangan.

\section{Zona E}

Tabel 8. Hasil Pengukuran Tingkat Iluminasi pada Zona E

\begin{tabular}{|c|c|c|c|c|c|c|}
\hline & \multirow{2}{*}{$\begin{array}{c}\text { Jumlah ruang } \\
\text { ukur }\end{array}$} & \multirow{2}{*}{ Jumlah titik ukur } & \multirow{2}{*}{$\begin{array}{l}\text { Rentang standar } \\
\text { iluminasi (EN) }\end{array}$} & \multicolumn{3}{|c|}{ Keterangan } \\
\hline & & & & $<$ & - & $>$ \\
\hline Merata & \multirow{2}{*}{46} & 2659 & 270-330 & $40.6 \%$ & $19.0 \%$ & $40.4 \%$ \\
\hline Bidang kerja & & 94 & $475-525$ & 85 & 6 & 3 \\
\hline
\end{tabular}

Pada zona E yang tidak mendapatkan penetrasi cahaya alami, tingkat iluminasi pada ruang cenderung kurang $(40,6 \%)$ dan melebihi $(40,4 \%)$ standar. Pada bidang kerja, hampir seluruhnya kurang dari standar (85 titik dari 94). Terdapat dua tipe ruang yaitu open plan dan kubikal.

Pada area ruang dosen teknik sipil dan arsitektur di mana tingkat iluminasi pada ruangan cenderung rendah mengimbangi tingkat iluminasi pada bidang kerja. Pada area ruang tata usaha, bidang kerja berada di tepi ruangan, padahal tingkat iluminasi yang baik berada di sekitar tengah ruangan. Hal ini kemudian menyebabkan tingkat iluminasi yang kurang optimal bagi penghuni ruang tata usaha yang pekerjaannya cenderung lebih intensif dibandingkan ruang kerja lain. 


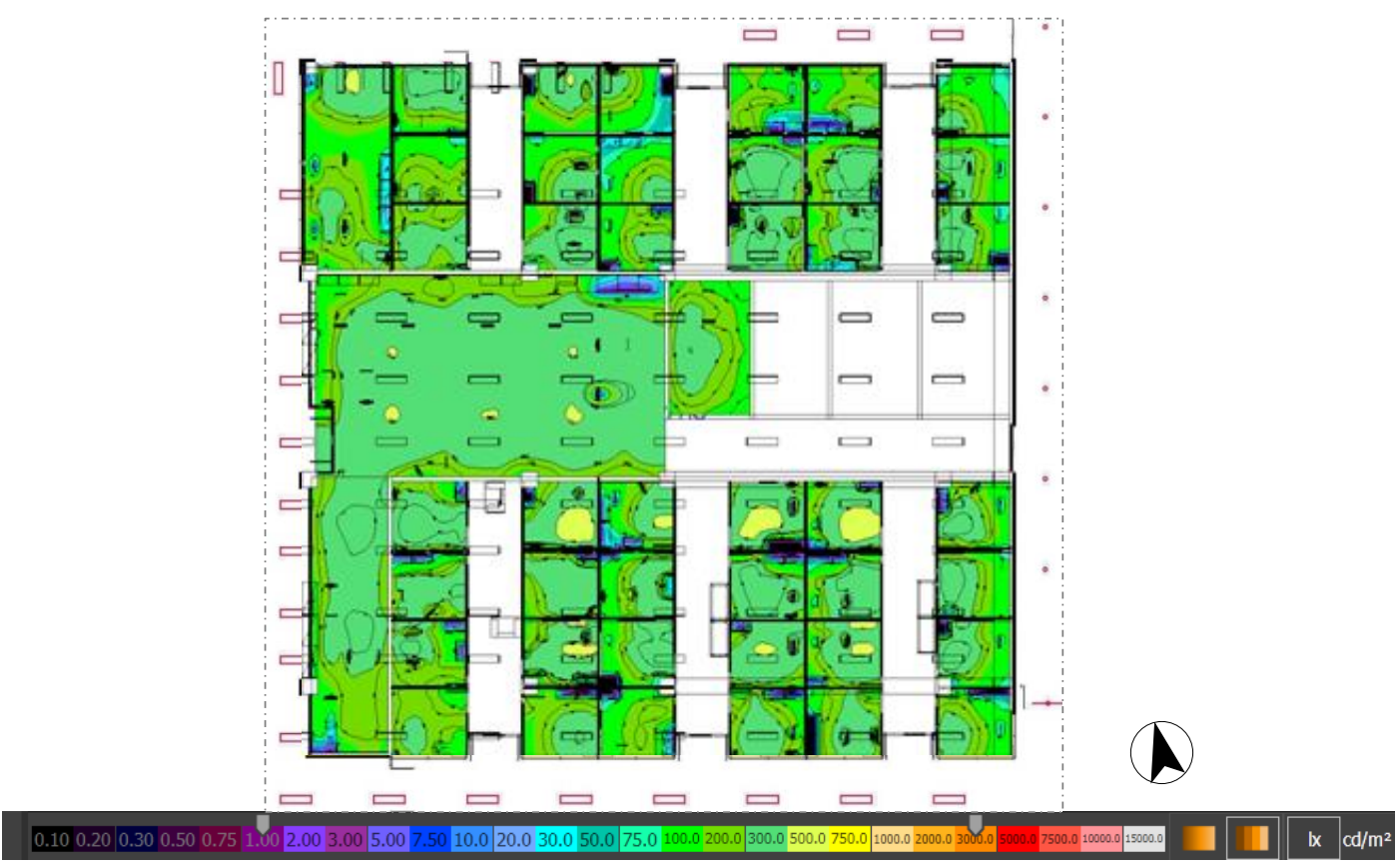

Figur 10. Pola distribusi pencahayaan buatan pada zona $\mathrm{E}$

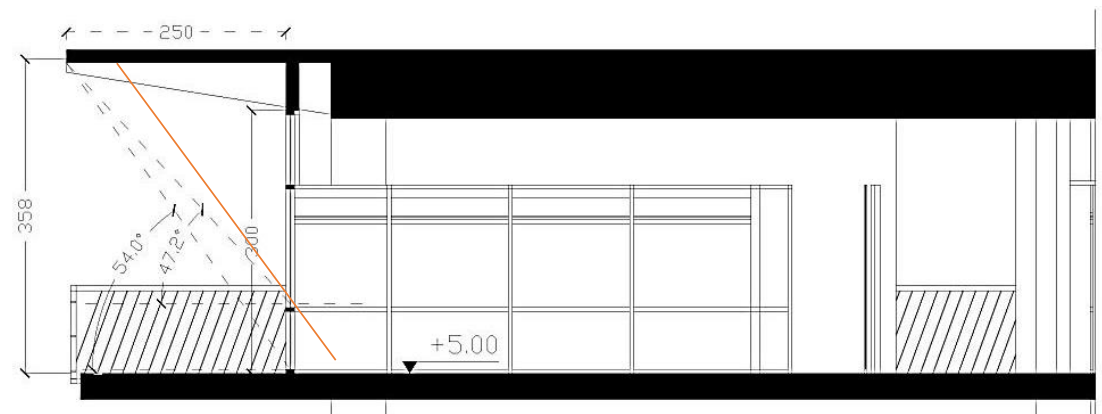

Figur 11. Dimensi vertikal ruangan

\subsection{SILAU}

Bangunan kantor PPAG memiliki sirip penangkal sinar matahari horizontal berupa teritis selebar $250 \mathrm{~cm}$ di sekeliling bangunan. Dengan dimensi teritis yang demikian, sudut pembayangan vertikalnya sebesar $54^{\circ}$. Setelah diketahui sudut pembayangan vertikalnya sebesar $54^{\circ}$, diketahui jam-jam kritis di mana sinar matahari memasuki ruangan menggunakan sun protractor.

\section{A. Silau Sinar Matahari}

\section{Zona A}

Untuk zona utara (zona A) potensi penetrasi sinar matahari dapat diabaikan karena tidak adanya lubang cahaya efektif (terbayangi oleh elemen penghalang). 


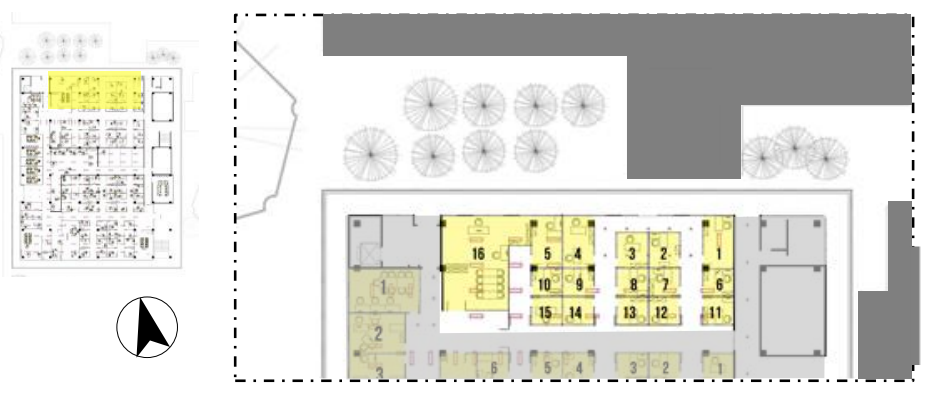

Figur 12. Kondisi ruang luar sekitar zona A

\section{Zona B}

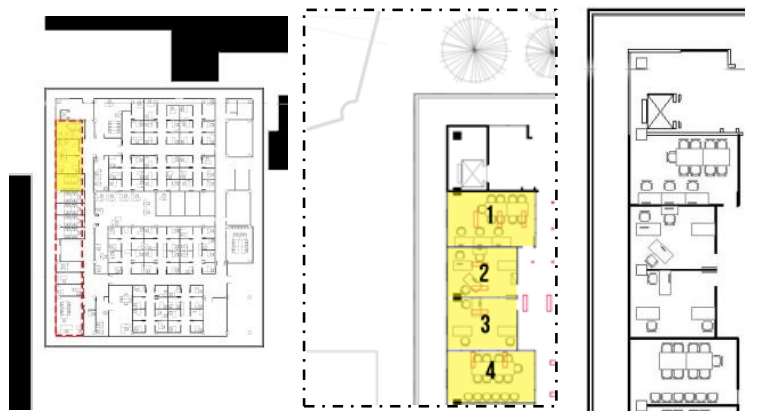

Figur 13. Kondisi ruang luar sekitar zona B yang berpotensi silau dan tata letak perabotnya

Tabel 9. Penetrasi Sinar Matahari di Zona B pada Pukul 16.00

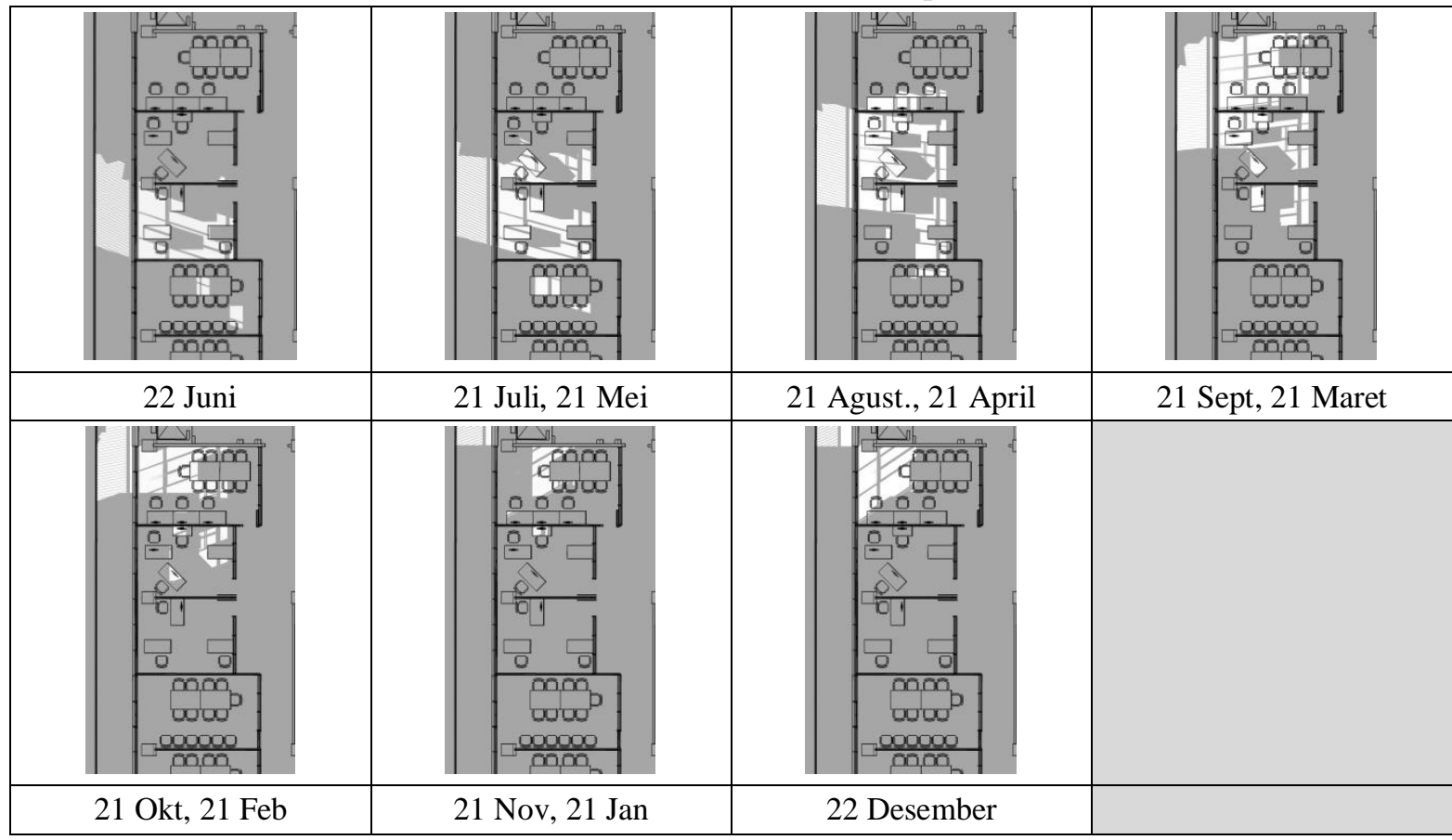

Pada zona barat (zona B), umumnya silau yang mengganggu mulai terlihat pada pukul 15.00, memberikan potensi silau langsung kepada penghuni yang duduknya sejajar dengan jendela. Cahaya matahari yang mengganggu bidang dan objek kerja terlihat pada pukul 15.30, menyebabkan kontras yang berkurang pada objek kerja. Pada orientasi barat, SPSM menjadi optimal apabila sudut pembayangannya adalah $25^{\circ}$ pada SPSM.

\section{Zona C}


Untuk zona selatan (zona C), penetrasi sinar matahari tidak menimbulkan silau langsung pada bidang kerja. Namun posisi layar monitor yang menghadap dengan bukaan dapat berpotensi silau oleh karena pencahayaan dari luar, sedangkan posisi layar monitor yang membelakangi bukaan memberikan rasio tingkat cerah yang kurang baik. Latar belakang monitor menjadi lebih cerah daripada bidang kerja, menyebabkan tingkat cerah pada layar monitor harus dinaikkan. Tingkat cerah pada monitor dapat menyebabkan ketegangan mata, dan pada batas tertentu dapat mengganggu kesehatan mata.

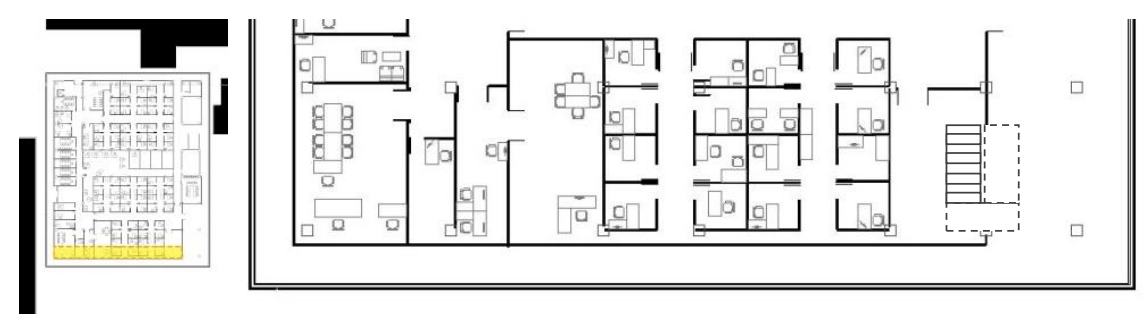

Figur 14. Kondisi ruang luar sekitar zona $\mathrm{C}$ yang berpotensi silau dan tata letak perabotnya

Tabel 10. Penetrasi Sinar Matahari di Zona C pada Pukul 16.00

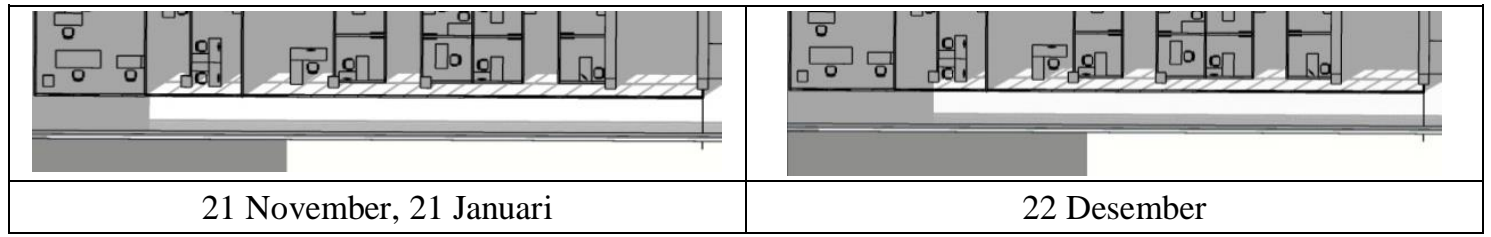

\section{Zona D}

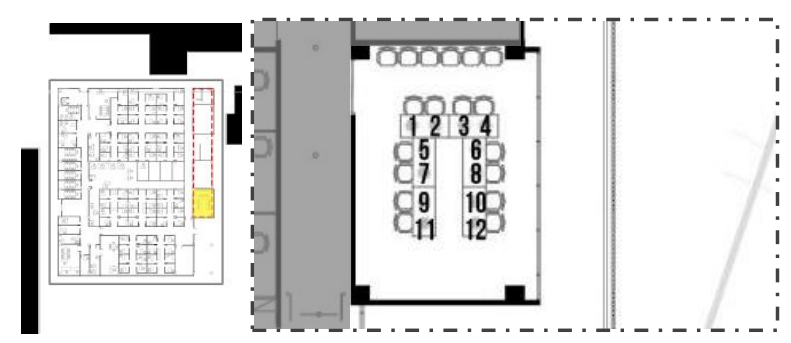

Figur 15. Kondisi ruang luar sekitar zona B yang berpotensi silau dan tata letak perabotnya

Tabel 11. Penetrasi sinar matahari di zona D pada pukul 08.00

\begin{tabular}{|c|c|c|c|c|c|c|}
\hline 22 Juni & $\begin{array}{l}21 \text { Juli, } 21 \\
\text { Mei }\end{array}$ & $\begin{array}{c}21 \text { Agust., } 21 \\
\text { April }\end{array}$ & $\begin{array}{l}21 \text { Sept, } 21 \\
\text { Maret }\end{array}$ & $\begin{array}{l}21 \text { Okt, } 21 \\
\text { Feb }\end{array}$ & $\begin{array}{l}21 \text { Nov, } 21 \\
\text { Jan }\end{array}$ & 22 Desembe \\
\hline \begin{tabular}{l|l|}
00000 \\
\\
\end{tabular} & 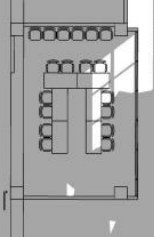 & 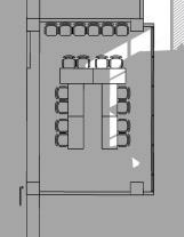 & 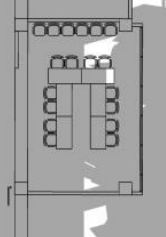 & 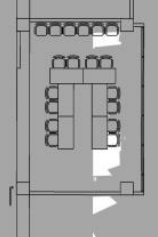 & 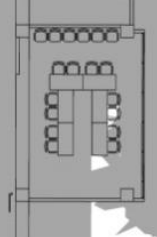 & 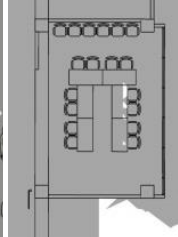 \\
\hline
\end{tabular}

Untuk zona timur (zona D), sinar matahari cenderung tidak menimbulkan silau pada bidang kerja dalam ruangan. Keberadaan pohon peneduh pada luar ruangan cukup berperan menghalau silau matahari pada orientasi ini. Silau cenderung terjadi pada pagi hari pukul 08.00, dan beberapa pada pukul 08.30. Pada orientasi timur, SPSM akan optimal bila sudut pembayangannya sebesar $30^{\circ}$, di mana SPSM akan menghalau sinar matahari masuk ke dalam ruangan, atau minimal $47^{\circ}$ agar tidak menimbulkan silau pada bidang kerja. 


\section{B. Silau Armatur Lampu}

\section{Silau pada Layar Monitor}

Armatur lampu pada tipe ruang open plan cenderung tidak menyinggung layar monitor karena letak layar monitor pada ruang ini berada di pinggir ruang yang membelakangi armatur lampu. Untuk tipe ruang kubikal memiliki potensi silau bila lampu berada di belakang pelaku aktivitas, dan orientasi kisi pendifus pada armatur lampu tidak sesuai.

Potensi silau juga dapat disebabkan karena keberadaan elemen perabot di sekitar monitor di belakang pelaku aktivitas. Namun karena warna material perabot (misalnya lemari) cenderung gelap (abu dan coklat), perabot tidak banyak memantulkan cahaya dan tidak menimbulkan gangguan meskipun perabot tersebut berhadapan dengan layar monitor.

\section{Silau pada Meja Kerja}

Pada tipe ruang kubikal, nilai pencahayaan yang memadai cenderung pada lampu yang posisinya di atas bidang kerja. Kondisi bidang kerja (meja) yang menggunakan kaca bening sebagai alasnya dapat menjadi bidang pemantul cahaya yang datang karena kebocoran sudut visual pada kisi diffuser dari armatur lampu tersebut. Hal ini menyebabkan silau ke mata pengamat.

\section{KESIMPULAN}

\subsection{TINGKAT ILUMINASI}

Pencahayaan pada ruang kantor PPAG secara merata dinilai cenderung berlebihan, yaitu sebesar 42,5\%. Namun titik ukur yang bernilai kurang dari 270 (kurang memadai) juga memiliki persentase yang hampir sebanding yaitu 38,6\%. Hal ini mengindikasikan bahwa distribusi pada ruang kantor kurang merata, disebabkan karena bentuk ruang kantor di kantor PPAG lebih banyak didominasi bentuk kubikal dibandingkan open plan, menyebabkan distribusi cahaya yang terdifus oleh stiker sandblast pada partisi atau terhalangi perabot.

Tabel 12. Hasil Pengukuran Tingkat Iluminasi secara Merata pada Kantor PPAG

\begin{tabular}{|c|c|c|c|c|c|}
\hline \multicolumn{6}{|c|}{ ILUMINASI MERATA } \\
\hline \multirow{2}{*}{$\begin{array}{c}\text { ZONA } \\
\text { RUANG }\end{array}$} & \multirow{2}{*}{$\begin{array}{l}\text { JUMLAH } \\
\text { R. UKUR }\end{array}$} & \multirow{2}{*}{$\begin{array}{c}\text { JML } \\
\text { TITIK } \\
\text { UKUR }\end{array}$} & \multicolumn{3}{|c|}{ JUMLAH TITIK: } \\
\hline & & & $<$ & - & $>$ \\
\hline A & 16 & 702 & 320 & 109 & 273 \\
\hline B & 12 & 799 & 193 & 109 & 497 \\
\hline $\mathrm{C}$ & 20 & 1315 & 560 & 317 & 438 \\
\hline $\mathrm{D}$ & 1 & 77 & 4 & 14 & 59 \\
\hline $\mathrm{E}$ & 46 & 2659 & 1064 & 503 & 1092 \\
\hline \multicolumn{3}{|c|}{ TOTAL } & 2141 & 1052 & 2359 \\
\hline \multicolumn{3}{|c|}{ TOTAL (\%) } & 38.56 & 18.95 & 42.49 \\
\hline
\end{tabular}

Tabel 13. Hasil Pengukuran Tingkat Iluminasi pada Bidang Kerja di Kantor PPAG

\begin{tabular}{|c|c|c|c|c|c|c|c|c|c|c|c|}
\hline \multicolumn{12}{|c|}{ ILUMINASI PADA BIDANG KERJA } \\
\hline \multirow{3}{*}{$\begin{array}{c}\text { ZONA } \\
\text { RUANG }\end{array}$} & \multirow{3}{*}{$\begin{array}{c}\text { JUMLAH } \\
\text { RUANG } \\
\text { UKUR }\end{array}$} & \multirow{3}{*}{$\begin{array}{c}\text { JUMLAH } \\
\text { TITIK } \\
\text { UKUR }\end{array}$} & \multirow{2}{*}{\multicolumn{3}{|c|}{$\begin{array}{l}\text { JUMLAH } \\
\text { TITIK (EN): }\end{array}$}} & \multicolumn{6}{|c|}{ KETERANGAN } \\
\hline & & & & & & \multicolumn{3}{|c|}{ R. Kerja } & \multicolumn{3}{|c|}{ R. Rapat } \\
\hline & & & $<$ & - & $>$ & $<$ & - & $>$ & $<$ & - & $>$ \\
\hline A & 16 & 36 & 36 & & & 28 & & & 8 & & \\
\hline B & 12 & 74 & 50 & 10 & 14 & 17 & 2 & 6 & 33 & 8 & 8 \\
\hline
\end{tabular}




\begin{tabular}{|c|c|c|c|c|c|c|c|c|c|c|c|}
\hline $\mathrm{C}$ & 20 & 46 & 33 & 6 & 7 & 24 & 3 & 4 & 9 & 3 & 3 \\
\hline $\mathrm{D}$ & 1 & 12 & & 2 & 10 & & & & & 2 & 10 \\
\hline $\mathrm{E}$ & 46 & 94 & 85 & 6 & 3 & 85 & 6 & 3 & & & \\
\hline \multicolumn{3}{|c|}{ TOTAL } & 204 & 24 & 34 & 144 & 11 & 13 & 50 & 13 & 21 \\
\hline \multicolumn{3}{|c|}{ TOTAL (\%) } & 77.9 & 9.3 & 12.8 & 86.5 & 6.2 & 7.3 & 59.5 & 15.5 & 25 \\
\hline
\end{tabular}

Pola tingkat iluminasi yang berlebih pada ruang kantor PPAG terutama berada di bawah lampu dan sudut distribusi cahaya antar lampu yang bersinggungan, sedangkan yang nilainya kurang memadai berada pada tepi ruangan. Hal ini mengindikasikan bahwa jarak vertikal lampu pada kantor PPAG terlalu dekat dengan area kerja, sehingga distribusi cahayanya terkonsentrasi pada daerah bawah lampu. Tingkat iluminasi yang tinggi juga dipengaruhi oleh adanya penetrasi pencahayaan alami, terutama pada daerah selatan (zona C) di mana kondisi ruang luarnya tidak terdapat elemen pembayangan dan meskipun sudah didifus oleh stiker sandblast.

\subsection{SILAU MATAHARI}

Potensi silau pada bidang kerja di kantor PPAG hanya terjadi pada orientasi barat dan timur. Pada orientasi utara tidak terjadi potensi silau karena adanya elemen penghalang di sepanjang bukaan. Oleh karena orientasi bangunan miring sebesar $+11^{\circ}$ dari sumbu utara, menyebabkan SPSM selatan cenderung efektif, dan penetrasi sinar mataharinya tidak menimbulkan silau pada bidang kerja.

\subsection{PERFORMA VISUAL PADA KANTOR PPAG}

Performa visual pada kantor PPAG ditinjau dari tingkat iluminasi dan potensi silau dinilai kurang sesuai/efisien. Kuat iluminasi yang kurang terang terutama pada ruang kerja dosen yang sifatnya kubikal perlu dilakukan peningkatan. Ditambah lagi tugas visual yang cenderung berukuran kecil serta kondisi pengguna bangunan yang juga banyak dihuni oleh karyawan berumur di atas 40 tahun yang berarti adanya pengurangan kemampuan visual. Tingkat iluminasi yang kurang memadai \& ukuran tugas yang kecil dapat menyebabkan pupil mata pelaku aktivitas membesar untuk memperbanyak cahaya yang masuk ke mata. Pembesaran pupil menyebabkan mata mudah lelah.

Performa visual dapat dioptimalkan dengan penempatan zoning yang sesuai, peletakkan perabot yang tepat, dan juga penggunaan elemen-elemen arsitektural tambahan. Saran untuk pengoptimalan kondisi lingkungan visual pada kantor PPAG adalah sebagai berikut.

\section{Cahaya Buatan}

Mengganti lampu LED pada ruang kerja dengan lampu yang memadai. Penggantian lampu TL untuk meningkatan kuat iluminasi direkomendasikan untuk menjadi alternatif kedua karena menurut literatur dapat menyebabkan peningkatan tingkat cerah, dan dapat berpotensi silau. Penggunaan lampu lokal untuk mendukung penerangan dari lampu TL menjadi alternatif utama, sehingga pencahayaan dapat lebih di kontrol tanpa meningkatkan silau sekaligus menjadi upaya penghematan energi.

Alternatif di atas dapat dilengkapi dengan penambahan jarak antar luminer lampu, misalnya dengan mengganti armatur lampu yang lebih lebar. Tujuannya agar distribusi lampu lebih merata.

\section{Cahaya Alami}




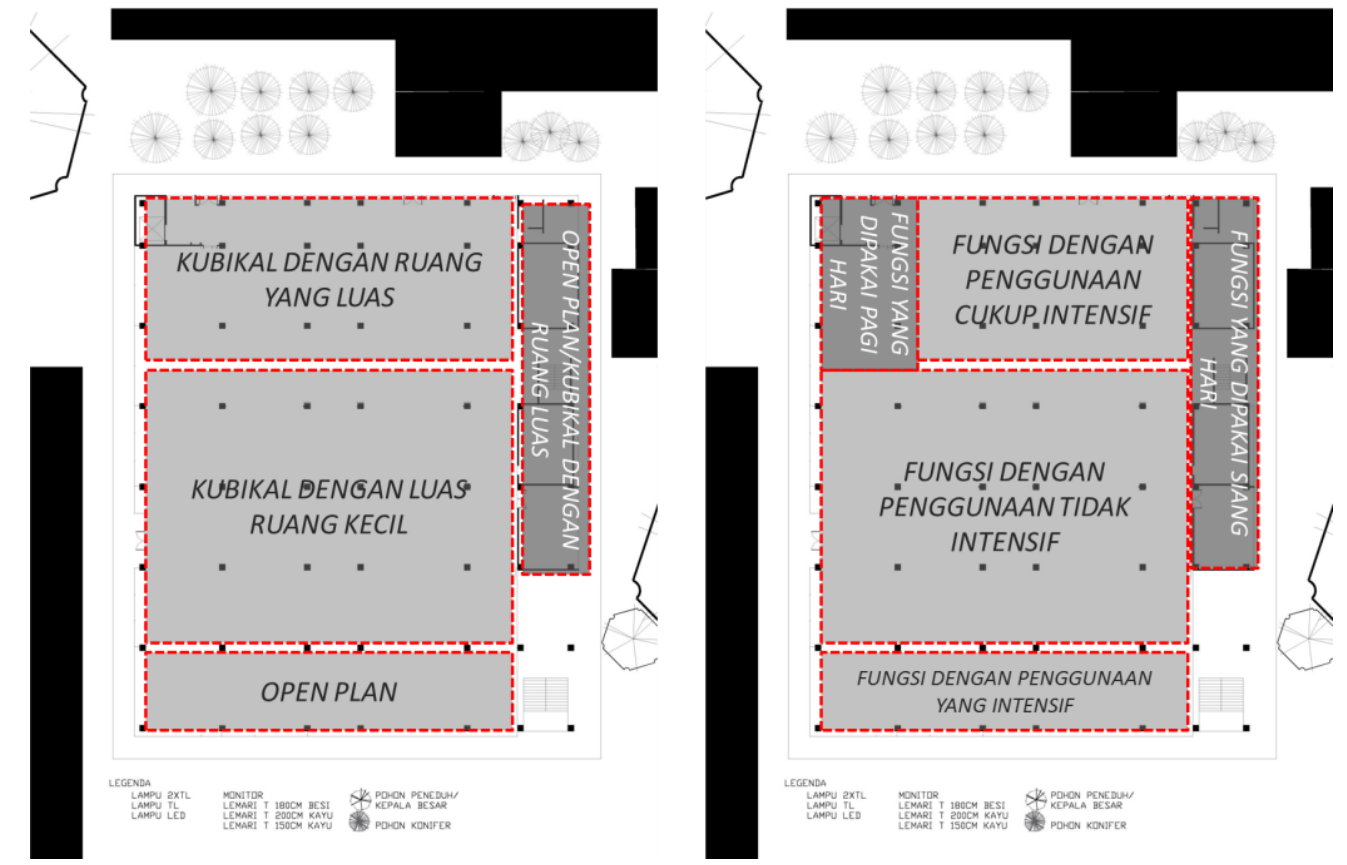

Figur 16. (a) Saran zonasi berdasarkan tipologi ruang; (b) Saran zonasi berdasarkan fungsi ruang

Kontribusi cahaya alami dapat dimaksimalkan untuk menambahkan tingkat iluminasi pada ruang dan bidang kerja. Cara memaksimalkannya dengan mengatur zonasi ruang tata usaha sebagai penghuni dengan jam kerja yang tetap/intensif di daerah selatan (zona C) pada zona dengan penetrasi cahaya alami paling besar, dan ruang yang penggunaannya tidak intensif seperti ruang rapat berada di area tengah ruang yang tidak mendapat penetrasi cahaya alami. Pengaturan lain juga dengan meletakkan ruang yang luas atau open plan pada daerah tepi dengan lubang cahaya yang efektif, sehingga cahaya alami tidak terdifus oleh partisi. Hal ini digambarkan pada figur 16(a).

Untuk mengantisipasi silau, penangkal sinar matahari pada orientasi barat dapat dimaksimalkan dengan bentuk SPSM kisi-kisi. Selain SPSM, alternatif lain juga dapat dengan menggunakan tirai yang arah bukanya horizontal, sehingga penetrasi cahaya alami dalam ruang dapat dikontrol menyesuaikan kebutuhan, yaitu memasukkan cahaya alami ke dalam ruang namun tidak menimbulkan silau pada waktu tertentu. Untuk orientasi selatan tidak diperlukan antisipasi. Untuk orientasi timur di mana terdapat penetrasi cahaya matahari namun tidak selalu menimbulkan silau pada bidang kerja, antisipasi dilakukan dengan penggunaan SPSM kisi-kisi atau dengan penggunaan vertical blind dengan panjang minimal hingga ketinggian bidang kerja. Antisipasi lain dapat pula dilakukan zoning ulang dengan ruang yang tidak digunakan pada pagi hari di area timur, dan ruang yang jarang digunakan pada siang hingga sore hari di area barat. Hal ini digambarkan pada figur 16(b).

\section{Material Elemen Pengisi}

Mengganti elemen kaca bening pada meja kerja dengan material yang sifatnya lebih mendifus cahaya seperti penggunaan kaca es, agar permukaan bidang kerja tidak memantulkan cahaya yang menyebabkan silau.

\section{DAFTAR PUSTAKA}

Buku

Bean, Robert. (2004). Lighting: Interior and Exterior. Oxford: Elsevier Ltd.

Ching, Francis D.K. (2012). Interior Design Illustrated. New Jersey: John Wiley \& Sons, Inc. 
Egan, D.M., Victor O. (2002). Architectural Lighting. New York: McGraw-Hill.

Karlen, Mark, Benya, James R. (2004). Lighting Design Basics. Canada: John Wiley \& Sons, Inc.

Lechner, Norbert. (2015). Heating, Cooling, Lighting. New Jersey: John Wiley \& Sons, Inc.

Pacific Energy Center (1997). Pacific Energy Center Factsheet: Understanding Visual Performance. Pacific Gas and Electric Company.

Ruck, N. C. (1989). Building Design and Human Performance. New York: Van Nostrand Reinhold.

Steffy, G. (2002). Architectural Lighting Design. New York: John Wiley \& Sons, Inc.

Skripsi, Thesis, dan Penelitian

Zumtobel (2017). The Lighting Handbook. Austria: Zumtobel Lighting GmbH.

SNI (2001). SNI 03-2396-2001 Tata Cara Perancangan Sistem Pencahayaan Alami pada Bangunan Gedung. Jakarta: Badan Standardisasi Nasional.

SNI (2001). SNI 03-6575-2001 Desain Pencahayaan Buatan. Jakarta: Badan Standardisasi Nasional.

SNI (2004). SNI 16-7062-2004 Pengukuran Intensitas Penerangan di Tempat Kerja. Jakarta: Badan Standardisasi Nasional.

Akhtar, N., Saqib A., Muhammad S., Asad U. R., Aqsa I. (2014) Interior Design and Its Impact on of Employee's Productivity in Telecom Sector, Pakistan.

\section{Website}

Calleja, H., Pérez A.R., Fernando (2015). Conditions Required for Visual Comfort. Diakses tanggal 29 Agustus 2017, dari http://www.iloencyclopaedia.org/part-vi-16255/lighting/80-46lighting/conditions-required-for-visual-comfort 